\title{
Application of Treffinger Learning Model to Improve Creative Reasoning and Mathematical Problem Solving Skills as Well as Student Learning Interests
}

\author{
Jaka Wijaya Kusuma1, Ulfi Jefri' ${ }^{2}$, Ardi Hidayat ${ }^{3}$, Hamidah ${ }^{4}$ \\ ${ }^{1234}$ Mathematics Education, Universitas Bina Bangsa, Serang, Indonesia \\ 1jakawijayak@gmail.com, ${ }^{2}$ ulfijefri.binabangsa@gmail.com, \\ 3ardihidayat89@gmail.com, ${ }^{4}$ shiroimida@gmail.com
}

\begin{abstract}
Article History:

Received : 31-08-2020

Revised : 16-09-2020

Accepted : 17-09-2020

Online : 03-10-2020

Keyword:

Creative reasoning;

Mathematical problem

solving;

Learning interests;

Treffinger.

In the learning process it is very important to try to get students to think creatively in solving problems and engaging actively. This research is an experiment in the form of design pretest postest control group design. The subjects in this study were two classes of 62 grade VIII junior high school students. The instruments used are tests of creative reasoning skills and mathematical problem solving in the form of 5 essay questions and learning interest questionnaires. Analyze data using Gain test, Chi Square test and Contingency Coefficient. The results found that improved creative reasoning skills as well as the mathematical problem-solving abilities of students with Treffinger learning were superior to regular learning. In addition, it was also found that the higher the student's learning interest the higher their creative reasoning skills and mathematical problem solving skills. Other findings include associations between students' learning interests, mathematical creative reasoning skills and students' mathematical problem-solving skills classified as moderate.
\end{abstract}

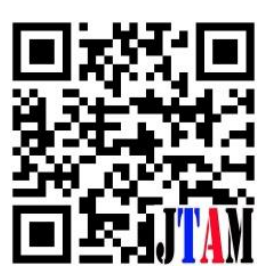

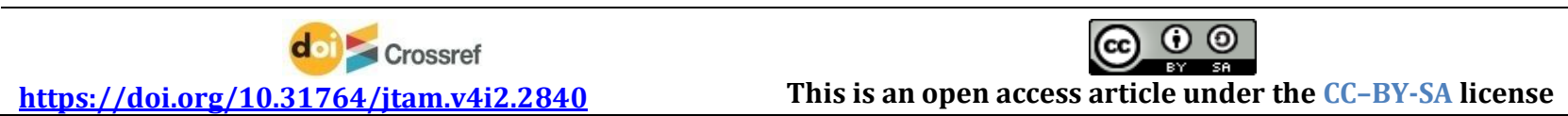

\section{A. INTRODUCTION}

Mathematics has a very important role in students' lives now and then. So it needs special attention in succeeding the mathematical learning process. Great expectations for many so that students have good competence, students are conducive to learning, have good high level of math thinking skills, and students are active. But the reality is that the competencies of students are limited, students lack the confidence to be active in learning, and students are too busy recording the materials provided. This is in accordance with the opinion (Juanti et al., 2016) that students only memorize the concept and are less able to use the concept if they encounter problems in real life related to the concept. 
The principle of learning mathematics emphasizes students to learn with understanding and reasoning, actively building new knowledge from previous experience and knowledge (Hakim et al., 2018). Furthermore according to (Fadillah, 2019) there are two types of reasoning that students often use in solving math problems, namely creative reasoning and imitative reasoning. The fact in the field is that very few students use creative reasoning in solving math problems.

Results from the study (Haqi et al., 2017) are known to average the percentage of difficulties experienced by students in Bandung in working on reasoning questions is 63.25\% and teachers in schools still tends to find it difficult to teach students using reasoning questions. In addition, the result of this research is knwon that (Olssom, 2018) student reasoning is a thought process in which students observe and try to complete tasks. This shows that creative reasoning influences the learning process of mathematics, and creative reasoning can improve students' problem solving skills.

According to (Putri et al., 2019) although mathematics is an important formal education and the lessons are very much related to human life but for math students is not something interesting. The results also showed that the math problem solving skills of Indonesian students are still low. In math learning, generally math problems are made so complex that students feel un confident and immediately find it difficult to solve them even before trying.Basic mathematical competencies include problem solving skills, reasoning skills and conceptual understanding. Further (Özsoy et al., 2015) in line with this objective, to bring up students' skills, in the learning process should more often invite students to solve problems. In solving problems, students refer to the use of necessary information through cognitive processes and problem elimination. According to (Muslim, 2017) there are four stages that Polya put forward in solving problems means understanding problems and making plans to find solutions, solving the problem as planned, and re-checking all the steps that have been taken.

Research (Putra, 2017) showed the results of the test of problem solving skills of students are still lacking. Further research (Juanti et al., 2016) mentioned that students' ability to solve problems is still low because to the large number of students who are less active in math learning in the classroom as well as in working on math problems. Furthermore, the results were known when students were given a description that corresponded to problem solving skills, from the problems given obtained $20 \%$ of students did one question correctly from the three questions given, $46.46 \%$ of students did two questions correctly out of three questions and $33 \%$ of students who could do all three questions correctly. From the above description it is known that students' math solving skills have not been satisfactory. The above demonstrates the need for special attention to students' mathematical abilities, especially problem solving skills and mathematical creative reasoning.

The learning process of mathematics is one of the important components in improving student competency. Therefore, it is necessary to have an interesting, varied, and always engaging learning model that engages students to be active thus positively affecting students' math skills, especially creative reasoning skills and mathematical problem solving. According to the results of the study (Handayani et al., 2018) Treffinger's learning model demands students in creative thinking. Furthermore according to (Wirahayu \& Purwito, 2018) 
Treffinger model is a learning strategy developed from a creative learning model that is mentally developed and prioritizes process.

Treffinger's learning model is one of three stage learning models that encourages students to use their creative reasoning skills in solving problems and has many alternatives in solving mathematical problems. This is in line with the opinion (Maharani \& Indrawati, 2018) that treffinger learning model is a model that seeks to invite students to think creatively in solving msalah by paying attention to the important facts that are around then bringing up various ideas and choosing the right solutions to implement in real time.

Students who have no interest in learning mathematics then want to be involved in the learning process is not expected to have an adverse effect on the student's mathematical ability. Based on the report of the results of mathematics learning seminar conducted by (Kusuma \& Hamidah, 2019) which is one of the causes of low interest in learning Indonesian students in learning mathematics is teachers teaching mathematics with un interesting materials and methods. In line with this background, this study takes the title "Improving creative reasoning and mathematical problem solving skills as well as learning interest of junior high school students through Treffinger learning model at State Junior High School 01 Carenang (called SMP Negeri 01 Carenang)".

In general, the problem formulations in this study are:

1. Is the improvement of creative reasoning and mathematical problem solving skills of middle school students who acquire Treffinger learning models better than those who acquire regular learning?

2. Is the learning interest of junior high school students who acquire Treffinger learning models better than those who acquire regular learning?

3. Is there an association between mathematical creative reasoning skills and students' mathematical problem solving skills?

4. Is there an association between learning interests and creative reasoning skills and with students' mathematical problem solving skills?

This research aims to examine in depth Treffinger 's learning role towards improving creative reasoning and mathematical problem solving skills and students' learning interests. Furthermore, the association was reviewed between creative reasoning skills, mathematical problem solving, and student learning interests. In addition, based on the findings will be sought efforts to overcome these difficulties and efforts to improve the next mathematical power.

The following presented operational definitions of the variables involved in this study.

1. Mathematical creative reasoning ability is the ability of reasoning in the solving of mathematical tasks. The indicators are:
a. Novelty is to create a new set of solutions to solve mathematical problems.
b. Flexibility is to create different ways of solving mathematical problems.
c. It makes sense (Plausibility) to make arguments that support the application of the strategy used so as to corroborate the reason that the conclusions made are correct.
d. The mathematical foundation is an argument given in mathematical intrinsic traits.

2. Mathematical problem solving ability is the ability to find answers or solutions contained in mathematical problems. The indicators are: 

a. Understanding mathematical issues
b. Create a wrong name solver design
c. Implement problem solving plans
d. Re-examine troubleshooting results

3. The interest in learning mathematics is the interest and desire to be involved in the mathematical learning process. Interest indicators are:
a. Curiosity
b. Openness to experience
c. Sensation seeking
d. Boredom propeness
e. Breadth interest

4. Treffinger learning model is a learning process consisting of three steps namely basic tools, practice with process, and working with real problems.

\section{B. METHODS}

This research is an experiment in the form of post-test control group design design that aims to study Treffinger 's learning role on creative reasoning skills and mathematical problem solving as well as interest learning junior high school students. The population in this study was all state junior high school students in Serang, while the sample was 62 grade VIII students in one of the junior high school stipulated purposively and selected two grade VIII randomly from the existing grade VIII. Then the sample is randomly assigned which becomes the experiment class and the control class. Thus the research design Table 1:

Table 1. Research Design

\begin{tabular}{ccc}
\hline Pre-test & Treatment & Post-test \\
\hline 0 & $\mathrm{X}_{1}$ & 0 \\
0 & $\mathrm{X}_{2}$ & 0 \\
\hline
\end{tabular}

Description: $\mathrm{X}_{1}$ : Treffinger Learning, $\mathrm{X}_{2}$ : Regular learning, 0 : Test creative reasoning skills and mathematical problem solving. To see the research steps presented in Table 2 as follows:

Table 2. Research Measures

\begin{tabular}{|c|c|c|c|}
\hline $\begin{array}{l}\text { Nature of } \\
\text { The Study }\end{array}$ & Method & Research Measures & Expected exterior \\
\hline $\begin{array}{l}\text { Theoretical, } \\
\text { Empirical }\end{array}$ & $\begin{array}{l}\text { Theoretical } \\
\text { study } \\
\text { documentation }\end{array}$ & $\begin{array}{l}\text { 1. Identification of } \begin{array}{r}\text { creative } \\
\text { reasoning }\end{array} \\
\text { mathematical problem } \\
\text { solving skills, learning } \\
\text { interests, } \\
\text { materials, and the initial } \\
\text { condition of students }\end{array}$ & $\begin{array}{lcr}\text { Data on } & \text { students' } & \text { early } \\
\text { conditions } & \text { and } & \text { learning } \\
\text { difficulties. } & & \end{array}$ \\
\hline $\begin{array}{l}\text { Empirical } \\
\text { Rational } \\
\text { Theoretical }\end{array}$ & $\begin{array}{l}\text { Descriptive } \\
\text { analysis studies }\end{array}$ & $\begin{array}{l}\text { 2. Design samples of teaching } \\
\text { materials and instruments } \\
\text { for research. }\end{array}$ & $\begin{array}{l}\text { Design of teaching materials and } \\
\text { instruments with regard to } \\
\text { creative reasoning skills and } \\
\text { mathematical problem solving }\end{array}$ \\
\hline
\end{tabular}




\begin{tabular}{|c|c|c|c|}
\hline $\begin{array}{l}\text { Nature of } \\
\text { The Study }\end{array}$ & Method & Research Measures & Expected exterior \\
\hline & & & and Treffinger learning models. \\
\hline $\begin{array}{l}\text { Empirical } \\
\text { Rational } \\
\text { Theoretical }\end{array}$ & $\begin{array}{l}\text { Descriptive } \\
\text { analysis studies }\end{array}$ & $\begin{array}{l}\text { 3. Test samples of teaching } \\
\text { materials and instruments. }\end{array}$ & $\begin{array}{l}\text { Teaching materials and tests of } \\
\text { creative reasoning skills and } \\
\text { revised mathematical problem } \\
\text { solving. }\end{array}$ \\
\hline $\begin{array}{l}\text { Rational } \\
\text { empirical } \\
\text { naturalist }\end{array}$ & $\begin{array}{l}\text { Descriptive } \\
\text { analysis } \\
\text { studies, }\end{array}$ & $\begin{array}{l}\text { 4. Carry out research in terms } \\
\text { of learning, data analysis, } \\
\text { analysis of learning } \\
\text { implementation, reports, } \\
\text { attachments and seminars / } \\
\text { publications of research } \\
\text { results. }\end{array}$ & $\begin{array}{l}\text { Research reports and articles for } \\
\text { seminars and/or published in } \\
\text { nationally accredited scientific } \\
\text { journals and/or proceedings of } \\
\text { national/international } \\
\text { standards. }\end{array}$ \\
\hline
\end{tabular}

As for the relationship between problem formulation, Hypothesis, Data Group and Statistical Test Type used in data analysis is presented in Table 3.

Table 3. Related Problems, Hypotheses, Data Groups and Statistical Test Types used in Data Analysis

\begin{tabular}{lccc}
\multicolumn{1}{c}{ Problems } & Hypothesis & $\begin{array}{c}\text { Statistical Test } \\
\text { Type }\end{array}$ \\
\hline $\begin{array}{l}\text { Improved mathematical creative reasoning skills of junior high } \\
\text { school students who obtained Treffinger learning models better } \\
\text { than those who gained regular learning. }\end{array}$ & $\begin{array}{l}\text { Gain Test and T } \\
\text { Test }\end{array}$ \\
\hline $\begin{array}{l}\text { Improved mathematical problem solving skills of middle school } \\
\text { students who obtained Treffinger learning models better than } \\
\text { those who gained regular learning. }\end{array}$ & 2 & $\begin{array}{l}\text { Gain Test and T } \\
\text { Test }\end{array}$ \\
\hline $\begin{array}{l}\text { The learning interests of middle school students who acquire } \\
\text { Treffinger learning models are better than those who get regular } \\
\text { learning. }\end{array}$ & 3 & T Test \\
\hline $\begin{array}{l}\text { There is an association between mathematical creative reasoning } \\
\text { skills and students' mathematical problem solving skills. }\end{array}$ & 4 & $\begin{array}{l}\text { Chi-Square and } \\
\text { Contingency } \\
\text { Coefficient }\end{array}$ \\
\hline $\begin{array}{l}\text { There is an association between learning interests and students' } \\
\text { mathematical creative reasoning skills. }\end{array}$ & 5 & $\begin{array}{l}\text { Chi-Square and } \\
\text { Contingency } \\
\text { Coefficient }\end{array}$ \\
\hline $\begin{array}{l}\text { There is an association between learning interests and students' } \\
\text { mathematical problem solving skills. }\end{array}$ & 6 & $\begin{array}{l}\text { Chi-Square and } \\
\text { Contingency } \\
\text { Coefficient }\end{array}$ \\
\hline
\end{tabular}

\section{RESULT AND DISCUSSION}

The following are presented the findings on creative reasoning skills and mathematical problem solving as well as students' learning interests as presented in Table 4 below. 
Table 4. Creative Reasoning Skills And Mathematical Problem Solving and Student Learning Interests

\begin{tabular}{|c|c|c|c|c|c|c|}
\hline \multirow{3}{*}{ Ability and Disposition } & \multicolumn{6}{|c|}{ Traffenger Learning Class( $(n=31)$} \\
\hline & \multicolumn{3}{|c|}{ Average } & \multicolumn{3}{|c|}{ Elementary School (SD) } \\
\hline & Pre & Pos & Gain & Pre & Post & Gain \\
\hline Creative Reasoning & 1,48 & 5,74 & 0,29 & 1,12 & 2,25 & 0,14 \\
\hline Troubleshooting & 2,26 & 8,65 & 0,47 & 1,48 & 1,85 & 0,11 \\
\hline \multirow[t]{2}{*}{ Learning Interests } & \multicolumn{3}{|c|}{120,96} & \multicolumn{3}{|c|}{11,04} \\
\hline & \multicolumn{6}{|c|}{ Regular Learning Class $(n=31)$} \\
\hline \multirow[t]{2}{*}{ Ability and Disposition } & \multicolumn{3}{|c|}{ Rerata } & \multicolumn{3}{|c|}{ SD } \\
\hline & Pre & Pos & Gain & Pre & Post & Gain \\
\hline Creative Reasoning & 1,13 & 4,45 & 0,23 & 1,15 & 1,82 & 0,86 \\
\hline Troubleshooting & 2,39 & 6,93 & 0,34 & 1,36 & 1,91 & 0,11 \\
\hline Learning Interests & \multicolumn{3}{|c|}{91,55} & \multicolumn{3}{|c|}{7,74} \\
\hline
\end{tabular}

Table 4 shows that descriptively creative reasoning and problem-solving skills of students who are given Traffenger learning are better than regular classes. To support the description of improved creative reasoning skills and mathematical problem solving that has been described, the analysis of student ability data is done through statistical tests using the average difference test. Furthermore, a test of the normality of creative reasoning data and mathematical problem solving and student learning interests as a whole obtained that the data is distributed normally. Based on these findings, the test of the difference in average ability and disposition above was conducted by testing the difference between the two averages (presented in Table 5).

Table 5. Recapitulation of Average Difference Test Results with T-Test Between Traffenger Learning and Ordinary Learning

\begin{tabular}{lcl}
\hline \multicolumn{1}{c}{$\begin{array}{c}\text { Ability and } \\
\text { Disposition }\end{array}$} & Sig. & \multicolumn{1}{c}{ Interpretation } \\
\hline $\begin{array}{l}\text { Mathematical Creative } \\
\text { Reasoning Capabilities }\end{array}$ & 0,005 & $\begin{array}{l}\text { Improved mathematical creative reasoning skills of junior high } \\
\text { school students who obtained Treffinger learning models better } \\
\text { than those who gained regular learning at a rate of significance } \\
\text { of } 5 \%\end{array}$ \\
\hline $\begin{array}{l}\text { Mathematical } \\
\text { Troubleshooting } \\
\text { Capabilities }\end{array}$ & 0,000 & $\begin{array}{l}\text { Improved math problem solving skills of junior high school } \\
\text { students who obtained Treffinger learning models better than } \\
\text { those who gained regular learning at a rate of significance of } 5 \%\end{array}$ \\
\hline & $\begin{array}{l}\text { The learning interest of junior high school students who acquire } \\
\text { Treffinger learning models is better than those who get regular } \\
\text { learning at a level of significance of 5\% }\end{array}$ \\
\hline
\end{tabular}

From the results of data analysis and processing, the following interpretations are obtained:

1. Improved creative reasoning skills and mathematical problem solving skills of junior high school students who obtained Treffinger learning models better than those who gained regular learning overall. In the learning class traffenger is classified as moderate. 
2. With regard to students' learning interests, it was found that the learning interests of middle school students who acquired Treffinger learning models were better than those who obtained regular learning. And it is known that students' learning interests in both classes are relatively moderate.

The existence of associations between creative reasoning skills, mathematical problem solving and student learning interests is analyzed using contingency between two variables. Results showed that the contingency coefficient (C) for mathematical creative reasoning capabilities and mathematical problem solving capabilities was 0.24 with Sig. 0.001 in other words there is an association between mathematical creative reasoning skills and significant student mathematical problem solving skills at a rate of $5 \%$ significance in the moderate category. For the result of contingency coefficient (C) student learning interest and mathematical creative reasoning ability is 0.47 with Sig. 0,000 in other words there is an association between student learning interests and significant student creative reasoning skills at a rate of $5 \%$ significance in the moderate category. Furthermore for contingency coefficient results (C) students' learning interests and mathematical problem solving skills is 0.28 with Sig. 0.000 in other words there is an association between students' learning interests and significant student mathematical problem solving skills at a rate of $5 \%$ significance in the moderate category.

In this analysis, the findings found that students' learning interests play an important role in improving students' mathematical abilities, especially creative reasoning skills and students' mathematical problem solving skills. This is seen in the percentage of students whose learning interests are high but whose low math ability is greater than the percentage of students whose learning interests are low but whose math skills are high.

Treffinger mentions the steps of Treffinger's learning model consisting of three components, namely understanding challenge, generating ideas, and preparing for action. The steps of Traffinger's learning model are basic tools, work on process exercises, and use real problems in exercises (Rifa'i et al., 2020). During the learning process, students are divided into groups and given worksheets. In applying the Treffinger model, the end of learning is given a test question to know the ability of students after learning.

The Treffinger model prioritizes the creative process in developing its learning process as well as being mentally developed. According to (Elvita et al., 2020) Treffinger shows the mutual relationships and dependencies between them in encouraging creative learning. In his learning students are invited to create freely in solving the problems they face, while the role of the teacher continues to direct students to solve problems creatively according to the learning objectives they want to achieve. During learning teachers continue to stimulate students to think openly by gradually giving students more complex problems thus stimulating students to demonstrate their creative potential in solving problems. Furthermore teachers also provide problems involving students and encourage students to find their own solutions to the given problem.

However it was found that the student's failure to solve the problem was caused by the student's failure to operate mathematics, analyze with the most effective methods to understand the core of the problem and to observe and organize the operations performed. Nevertheless, the failure prompted students to try and continue to try to implement measures 
that were deemed appropriate in solving the problem. According to (Ozsoy \& Ataman, 2009) states that it is a fact that students who have high metacognitive skills will perform better in problem solving. It is supported by the statement (Eviyanti et al., 2017) that everyone has a varied solution in solving the problem depending on what is seen and observed in their mind.

Based on observations, the student process of solving problems is more organized, students try to solve complex problems by parsing the problem into simple problems. Not a few students ask their own questions to clarify the ideas they think about. This is because in each stage of the activity the Treffinger learning model has a clear goal of improving the expected cognitive and affective abilities. This is in accordance with the statement (Rohmah et al., 2020) that in the steps of treffinger learning model students are directed to apply new ideas and see as many ways as possible in solving problems.

Encouraging students to develop their reasoning skills indirectly triggers students' creative abilities. It also shows that creative reasoning skills will affect students' math learning achievement. Based on the results of the above analysis, the study proves that there is a positive and significant relationship between creative reasoning skills and problem solving abilities. According to (Ndiung et al., 2019) the creative learning process is a learning process that seeks to make the learning process communicative and able to change the learning situation to be comfortable for students.

Apart from the students' mathematical abilities, the results of this study also showed a positive student's interest in Treffinger learning. According to (Qomariyah, 2017) that can affect the learning achievement of students, among others, talents, and interests of students both from inside or outside the school and the community. In its stages, the Treffinger model gives students the freedom to freely solve problems in their own way. Moreover, students are presented with a concrete and based on the student's life so it is interesting to follow.

In the field, there are several weaknesses of treffinger learning model, namely that each student has different levels of knowledge in solving the given problem and the unpreparedness of students in dealing with new problems. In addition, researchers need time to prepare students for the stages of treffinger learning model.

\section{CONCLUSION AND SUGGESTIONS}

This study provides several conclusions, namely improved creative reasoning skills and mathematical problem solving of junior high school students who obtained a better treffinger learning model than those who gained regular learning. Furthermore, it is known that the learning interest of junior high school students who acquire treffinger learning models is better than those who acquire regular learning. Overall it is known that there is an association between mathematical creative reasoning skills and students' mathematical problem solving skills, and between learning interests and creative reasoning skills and with students' mathematical problem solving skills. With the association of each variable is classified as moderate.

The researcher's next suggestion is to research other mathematical abilities to study learning with the Traffinger model. Teachers should develop Traffinger learning models by better preparing teaching materials according to students' needs so that students' mathematical power development is better. Furthermore, teachers and readers should 
understand that it is important to increase students' learning interests to improve students' mathematical abilities.

\section{ACKNOWLEDGEMENT}

The team of authors thanked the Research and Community Service Institute (LP2M) of Bina Bangsa University for facilitating this research activity so that it was done properly. The writing team also thanked the principal of SMP in serang who has facilitated this research activity so that it is done properly. Not forgetting the authors to thank the teachers and students who have participated well and actively during the research activities.

\section{REFERENCES}

Elvita, A., Johar, R., \& Abidin, T. F. (2020). The development of learning tools using treffinger model assisted by geogebra to enhance students' creativity. Journal of Physics: Conference Series, 1460(1). https://doi.org/10.1088/1742-6596/1460/1/012045

Eviyanti, C. Y., Surya, E., Syahputra, E., \& Simbolon, M. (2017). Improving the Students' Mathematical Problem Solving Ability by Applying Problem Based Learning Model in VII Grade at SMPN 1 Banda Aceh Indonesia. International Journal of Novel Research in Education and Learning, 4(2), 138-144. https://www.researchgate.net/publication/318529138

Fadillah, A. (2019). Analisis Kemampuan Penalaran Deduktif Matematis Siswa. JTAM / Jurnal Teori Dan Aplikasi Matematika, 3(1), 15. https://doi.org/10.31764/jtam.v3i1.752

Hakim, W., Sulandra, I. M., \& Hidayanto, E. (2018). Penalaran Kreatif Siswa SMP dalam Menyelesaikan Masalah Sistem Persamaan Linier Dua Variabel ( SPLDV ). Jurnal Pendidikan, 3(5), 608-619.

Handayani, R., Hajidin, Duskri, M., \& Maidiyah, E. (2018). Development of learning tools using Treffinger learning model to improve creative thinking. Journal of Physics: Conference Series, 1088. https://doi.org/10.1088/1742-6596/1088/1/012090

Haqi, R., Susilawati, W., \& Juariah, J. (2017). Analisis Perbandingan Penalaran Kreatif Soal Ujian Nasional Matematika Tahun 2016 Tingkat Sekolah Lanjutan Atas. Jurnal Analisa, 3(2), 148-156. https://doi.org/10.15575/ja.v3i2.2016

Juanti, L., Santoso, B., \& Hiltrimartin, C. (2016). Peningkatan Kemampuan Pemecahan Masalah Siswa Menggunakan Model Pembelajaran Treffinger. Jurnal Tatsqif, 14(2), 198-217. https://doi.org/10.20414/jtq.v14i2.29

Kusuma, J. W., \& Hamidah. (2019). Pengaruh Model Pembelajaran ARIAS Dan Cooperative Script Terhadap Minat Dan Hasil Belajar Matematika. ANARGYA: Jurnal Ilmiah Pendidikan Matematika, 2(1), 64-69.

Maharani, R. K., \& Indrawati, D. (2018). Pengaruh Model Pembelajaran Treffinger Terhadap Kemampuan Berpikir Kreatif Pelajaran Matematika Materi Bangun Ruang. JPGSD Universitas Negeri Surabaya, 6(4), 506-515.

Muslim, S. R. (2017). Pengaruh Penggunaan Model Project Basedl Learning Terhadap Kemampuan Pemecahan Masalah Matematis Peserta Didik. Supremum Journal of Mathematics Education, 1(2), 88-95.

Ndiung, S., Dantes, N., Ardana, I. M., \& Marhaeni, A. A. I. N. (2019). Treffinger creative learning model with RME principles on creative thinking skill by considering numerical ability. International Journal of Instruction, 12(3), 731-744. https://doi.org/10.29333/iji.2019.12344a

Olsson, J. (2018). The Contribution of Reasoning to the Utilization of Feedback from Software When Solving Mathematical Problems. International Journal of Science and Mathematics Education, 16(4), 715-735. https://doi.org/10.1007/s10763-016-9795-x

Ozsoy, G., \& Ataman, A. (2009). The effect of metacognitive strategy training on mathematical problem solving achievement. International Electronic Journal of Elementary Education, 1(2), 68-82.

Özsoy, G., Kuruyer, H. G., \& Çakiroğlu, A. (2015). Evaluation of students' mathematical problem solving skills in relation to their reading levels. International Electronic Journal of Elementary Education, $8(1), 581-600$. 
Putra, F. G. (2017). Eksperimentasi Pendekatan Kontekstual Berbantuan Hands On Activity (HoA) Terhadap Kemampuan Pemecahan Masalah Matematik. Al-Jabar : Jurnal Pendidikan Matematika, 8(1), 73. https://doi.org/10.24042/ajpm.v8i1.1148

Putri, S. K., Hasratuddin, H., \& Syahputra, E. (2019). Development of Learning Devices Based on Realistic Mathematics Education to Improve Students' Spatial Ability and Motivation. International Electronic Journal of Mathematics Education, 14(2), 375-383. https://doi.org/10.29333/iejme/5729

Qomariyah, S. (2017). Hubungan antara Kemampuan Penalaran dengan Komunikasi Matematis Terhadap Pretasi Belajar Matematika. JTAM / Jurnal Teori Dan Aplikasi Matematika, 1(1), 49. https://doi.org/10.31764/jtam.v1i1.306

Rifa'i, R., Sujana, A., \& Romdonah, I. (2020). Penerapan model pembelajaran treffinger untuk meningkatkan kemampuan berpikir kreatif matematis siswa. Jurnal Analisa, 6(1), 1-9. https://doi.org/10.15575/ja.v6i1.4365

Rohmah, S., Kusmayadi, T. A., \& Fitriana, L. (2020). International Journal of Multicultural and Multireligious Understanding The Effect of the Treffinger Learning Model on Mathematical Connection Ability Students Viewed from Mathematical Resilience. International Journal of Multicultural and Multireligious Understanding, 7(5), 275-284.

Wirahayu, Y. A., \& Purwito, H. (2018). Penerapan Model Pembelajaran Treffinger Dan Ketrampilan Berpikir Divergen Mahasiswa. 9251(5), 30-40. 